\title{
Bank risk and performance in an emerging market setting: the case of Bangladesh
}

\author{
Md. Tofael Hossain Majumder \\ Donlinks School of Economics and Management, \\ University of Science and Technology Beiijing, China and \\ Department of Accounting and Information Systems, Comilla University, \\ Cumilla, Bangladesh, and \\ Xiaojing Li \\ Donlinks School of Economics and Management, \\ University of Science and Technology Beijing, Beijing, China

Xiaojing Li
Donlinks School of Economics and Management,
University of Science and Technology Beijing, Beijing, China

\begin{abstract}
Purpose - This study aims to investigate the impacts of bank capital requirements on the performance and risk of the emerging economy, i.e. Bangladeshi banking sector.

Design/methodology/approach - The study applies an unbalanced panel data which comprises 30 banks yielding a total of 413 bank-year observations over the period 2000 to 2015.

Findings - Using generalized methods of moments, the empirical results of this research reveal that bank capital is positively and significantly impressive on bank performance, whereas negatively and significantly impact on risk. The study also finds the inverse relationship between risk and performance in both the performance and risk equations. The results also indicate that there is a persistence of performance and risk from one year to the next year.

Originality/value - This is the unique investigation on Bangladeshi bank industry that considers the simultaneous effect of bank capital requirements on risk and performance. Therefore, it is predicted that the empirical evidence of this research shows policy implications to the regulatory authority of Bangladeshi banking industry to determine relevant policies.
\end{abstract}

Keywords Performance, Bangladesh, Capital, Bank risk, Generalized methods of moments

Paper type Research paper

\section{Introduction}

Over the past 20 years, several banking crises have taken place and increased concerns to the regulators about the financial stability system. Academicians, researchers and regulators

(C) Md. Tofael Hossain Majumder and Xiaojing Li. Published in Journal of Economics, Finance and Administrative Science. Published by Emerald Publishing Limited. This article is published under the Creative Commons Attribution (CC BY 4.0) licence. Anyone may reproduce, distribute, translate and create derivative works of this article (for both commercial and non-commercial purposes), subject to full attribution to the original publication and authors. The full terms of this licence may be seen at http://creativecommons.org/licenses/by/4.0/legalcode

This paper has been adopted from the author's unpublished Master thesis. The authors acknowledge the very constructive insights from the thesis committee members, reviewers of the thesis and to the Supervisor Dr Xiaojing Li of the Donlinks School of Economics and Management at the University of Science and Technology Beijing on earlier versions of this paper. 
JEFAS 23,46

200 identified several causes for maintaining the financial stability and urged for the stringent prudential regulation. The capital adequacy regulations play a prominent role for the prudential purposes compared to other tools proposed by the regulators (Altunbas et al., 2007).

To maintain the stable position in the international financial system, Basel Capital Accord named Basel I was introduced first in 1988. Because of the weaknesses of the Basel I, Basel II introduced in 2004. The prime objective of Basel Accord is to strengthen the bank's capital position and minimization of risks. Investigations into whether the Basel Capital Accord work effectively or not proliferated after the global financial crisis 2007-2008. As a result, in response to the global financial crisis, Basel III was introduced in 2010 by the Basel Committee on Banking Supervision. Regulators in most of the countries around the world are going to implement the Basel III step by step with varying timelines and methodologies. Already, many countries were adopted Basel II, for example, the European Union in 2008, Singapore in 2008, India in 2009 and Bangladesh in 2010. Needless to say, the recent financial crisis raised questions to the mind of the policy maker about the effectiveness of capital regulation and its effect on the bank risk and performance. It is thus no surprise to increase the concern about the investigation on the linkage between bank capital, risk and performance. Most of the empirical literature focuses on the relationship between capital, risk and profitability in US and European contexts (Demirguc-Kunt et al., 2013; Altunbas et al., 2007). However, the recent empirical research provides novel insights into the banking sector of alternative countries or regions, for example, the MENA (Middle Eastern and North African) regions (Bitar et al., 2016; Naceur and Omran, 2011), the Sub-Saharan African (Flamini et al., 2009), the Tunisia banking sector (Bennaceur and Goaied, 2008), the Egypt banking sector (Ben Naceur and Kandil, 2009) and the Asian banking sector (Zheng et al., 2017; Tan and Floros, 2013; Lee and Hsieh, 2013; Lee et al., 2015).

Despite the ongoing debate on the necessity of financial reforms, there is scant research on this topic, particularly in Asian countries. The research in the banking sector of the Asian countries is very important because banks are the main source of finance in the private sector of this region Lee and Hsieh (2013) and Deesomsak et al. (2004). Therefore, the banking sector of the Asian countries is the key laboratory for the investigation. To extend the research on Asian countries, this study endeavors to investigate the impact of bank capital on bank performance and risk in the banking sector of emerging economy. This investigation has considered Bangladesh as an ideal laboratory to examine the impact of bank capital on bank performance and risk. The study has considered Bangladesh as a benchmark economy for the investigations as it is one of the emerging economies. The study acknowledges with the study of Khan et al. (2013) that the definition of an "emerging economy" is problematic. However, Bangladesh has considered being the largest economies in the twenty-first century as one of the "next 11" emerging economies along with the BRIC countries by the global asset management company (Goldman Sachs) in 2005 (www.goldmansachs.com). In Bangladesh, several capital regulations reform has undergone over the last two decades, and the country achieved a consistent economic growth over six per cent after the millennium period (Zheng et al., 2017). Thus, the study recommends the significance of the country selection as Bangladesh. In addition, the investigation claims that the differences of national culture give different banking practices with different research findings (Zheng and Ashraf, 2014; Ashraf, 2017; Ashraf et al., 2016b). Therefore, the findings from Bangladesh will contribute to the existing literature significantly and will be effective for the other countries with a similar culture. To the best of my knowledge, this is the unique investigation on Bangladesh.

The previous empirical literature shows mixed results on the association between bank capital and risk. Some of the prior studies indicate there is a positive association between capital and risk, means the higher the capital ratio leads to the higher risk which is 
supported by the regulatory hypothesis (Iannotta et al., 2007; Demirgüç-Kunt and Huizinga, 2000). Existing theories suggest that the vital reason for introducing capital regulations is referred in the point of Moral Hazard Hypothesis (Demirgüç-Kunt and Kane, 2002; Hussain and Hassan, 2005). According to this hypothesis, there is a negative relationship between capital regulations and risk (Agusman et al., 2008; Jacques and Nigro, 1997). The State Preference Model uses by Liu et al. (1996) and Lin (1994) also finds a negative association between capital and risk. They claim that the level of risk exposures is reduced because of stricter capital management. In contrast, Lin et al. (2005), Blum (1999) and Keeley and Furlong (1990) used portfolio theory and questioned regarding the effectiveness of the capital management. They argue that banks are forced to have a greater level of risk exposures when the capital regulations tend to be strict. However, the puzzle between capital and risk, as suggested by Altunbas et al. (2007) and Hughes and Mester (1998), is that the association between Capital regulation and bank risk-taking is affected by the amount of profitability. Goddard et al. (2004) claim that the high ratio of capitalized bank earns a high profit and faces less risk.

From the above theoretical literature, it has observed that there is a puzzle between the bank capital, risk, and performance. The literature also shows inconclusive results on the relationship. Hence, there is still debate whether bank capital positively or negatively impacts the bank performance and risk. By considering the above fact, thus, this study attempts to find out the answer to the two questions. What is the impact of bank capital on the bank performance of Bangladesh? What is the impact of bank capital on the bank risk of Bangladesh?

This study is expected to play significance role for the academician, researcher, and policy maker because it contributes to the existing literature in several ways to fill the gap. First, this is the unique study addressing the impacts of capital requirement on both risk and performance simultaneously in the Bangladeshi banking sector. Also, this study is different from other studies because it uses two measures of capital, i.e. risk-based capital and non-risk-based capital. The existing literature indicates a debate about the capital requirements effectiveness. For example, Anginer and Demirgüç-Kunt (2014) and DemirgucKunt et al. (2013) argue what types of capital should use by the bank and what would be the structure of it. This is supported by the other researchers, Cathcart et al. (2015) and Dermine (2015), who shed doubts on the effectiveness of the risk-weighted assets in determining risk exposure of the bank. So, this paper adds value to the extant literature on highlighting the capital requirements effectiveness by examining the effect of risk-based and non-risk-based capital on bank risk and performance in Bangladesh. The study uses various measures of risk as well such as default risk, credit risk and overall risk.

Second, the prior literature on Bangladesh indicates a traditional association between capital and risk, risk and performance, but this study extends by adding capital and profit relationship with risk. The study is the complements of the recent studies of Bitar et al. (2016), Zheng et al. (2017), Lee et al. (2015) and Lee and Hsieh (2013).

Third, this research considers long period (2000-2015) of unbalanced panel data set of 30 commercial banks of Bangladesh.

Fourth, the study uses simultaneous equation modeling with generalized methods of moments (GMM) technique for the regression analysis to examine the simultaneous effect of bank capital requirement on risk and performance and testing the robustness of the results by using two-stage least squares (TSLS) regression.

Finally, the study trying to draw some suggestions regarding the influence of bank capital on the performance and risk in Bangladesh which will be beneficial not only for
Bank risk and performance

201 
JEFAS 23,46

202

Bangladesh but also for other countries of similar economic nature as well as for the academicians, researcher, and policy maker.

The remaining section of this study proceeds as follows. Section 2 provides about related literature. Section 3 shows the research methodology. Section 4 includes the analysis and findings. Section 5 summarizes the concluding remarks and indicates directions for the future researchers.

\section{Literature review}

This study divides the existing literature into three parts. The first part displays the existing literature related to the linkage between bank capital and performance. The second part of the study focuses on the related literature based on the association between bank capital and risk. Finally, the third part provides the literature related to variables used in the study.

\subsection{Nexus between bank capital and performance}

The prior literature indicates that bank performance is considered as an influential factor in the relationship between risk and capital (Lee and Hsieh, 2013; Moon and Hughes, 1997; Altunbas et al., 2007). Many researchers finds a positive association between capital and bank performance (Jacques and Nigro, 1997; Lin et al., 2005; Goddard et al., 2004; Rime, 2001; Lee and Hsieh, 2013; Naceur and Omran, 2011; Ben Naceur and Kandil, 2009; Mbizi, 2012). The positive relationship of prior literature emphasizes to hold more capital to increase bank performance. For example, Iannotta (2006) claims that banks are required to increase their capital ratios commensurably with the amount of risk taken by following the Basel guidelines. The author has mentioned that higher capital ratios diminish banks' leverage taking behavior and thus leads to their expected profits. Fiordelisi et al. (2011) argue that lower return induce bank management to choose a higher point on the efficiency frontier to improve their profits which leads to investments in riskier portfolios. As a result, a positive association should be expected between bank capital and performance. Zhang et al. (2008a) suggest that commercial banks, under the constraint of capital, should allocate resources and augment their business to increase liquidity and profitability. In contrast, differing from the positive relationship, Altunbas et al. (2007) find that inefficient European banks appear to hold more capital. Goddard et al. (2013) also concluded a negative association exists between profitability and capital in banks of nations from European Union member for the period 1992 to 2007. In addition, Guidara et al. (2013) conclude that there is no strong evidence that changes in capital buffer affect the profitability measured by ROE. Therefore, mixed results have found in the previous literature. Table I summarizes the previous literature in a more scientific way as follows.

\subsection{Nexus between bank capital and risk}

In the context of the implications of regulatory policies from the regulator, examination of the associations between risk and capital is considered as one of the important issues today (Lee and Hsieh, 2013). It is assumed that higher capital will have a positive impact on risk of the banking sector (Lee and Chih, 2013), but empirical results are mixed. Findings of some research reveal that there is a positive association between risk and capital (Shrieves and Dahl, 1992; Blum, 1999; Rime, 2001; Altunbas et al., 2007; Laeven and Levine, 2009; Kim and Santomero, 1988; Koehn and Santomero, 1980; Kahane, 1977; Lin et al., 2005). On the other hand, some studies find a negative relationship between risk and capital (Lee and Hsieh, 2013; Lee and Chih, 2013; Ho and Hsu, 2010; Zhang et al., 2008; Agoraki et al., 2011). Demirgüç-Kunt and Kane (2002) 


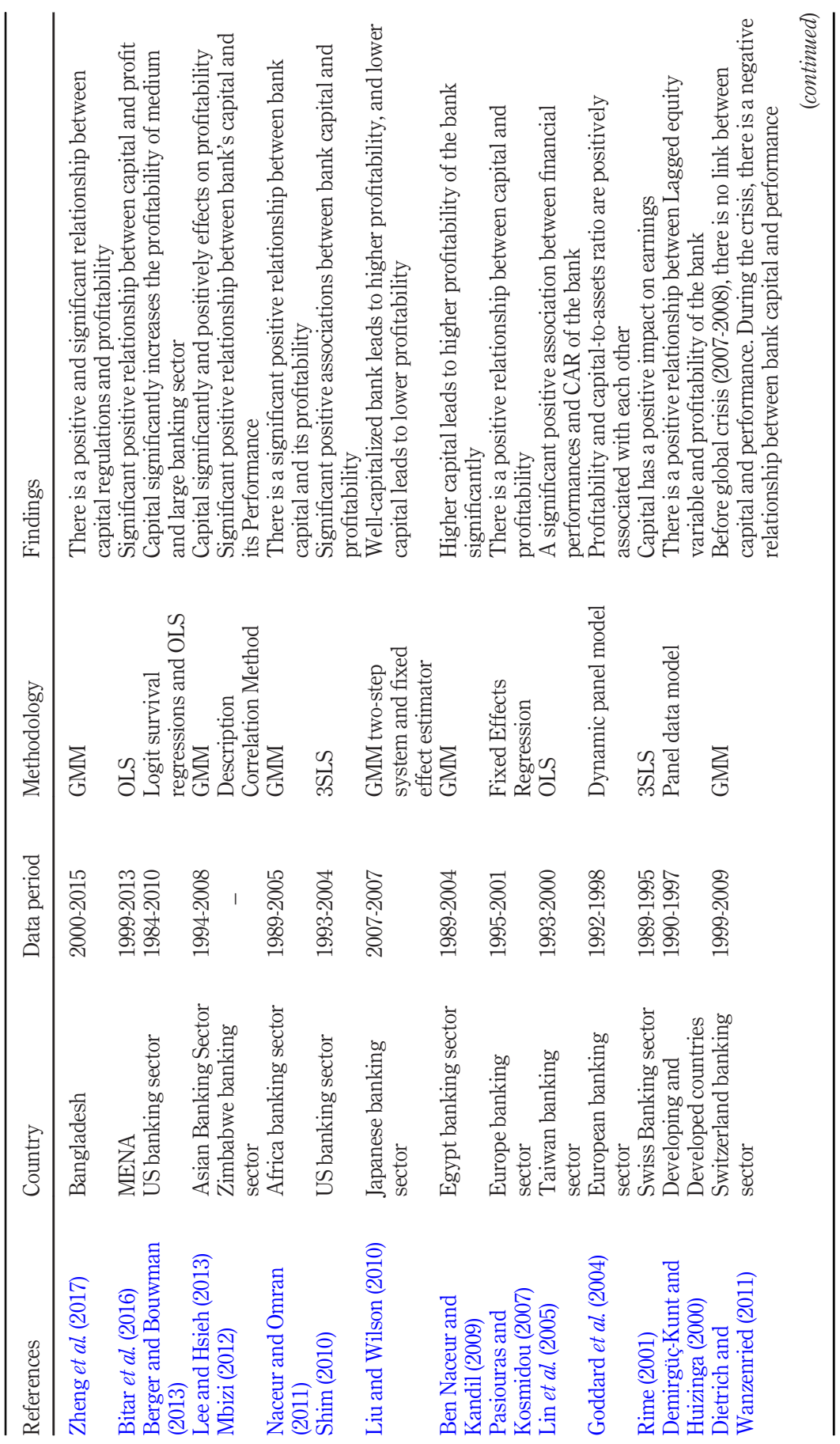

Bank risk and

203

Table I

Literature on the linkage between bank capital and performance 
JEFAS

23,46

\section{4}

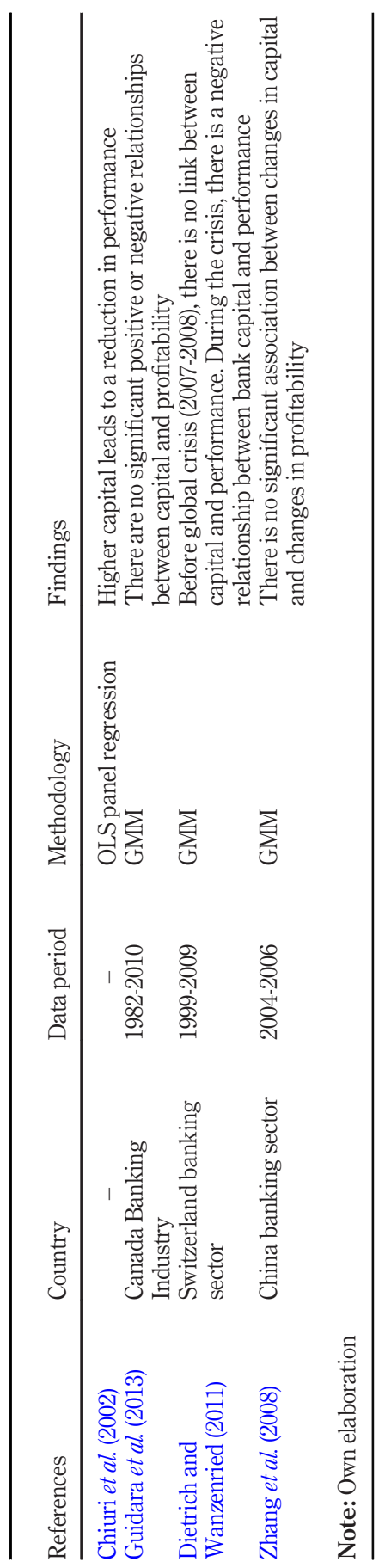


argue that the negative association between capital and risk may be referred as moral hazard hypothesis $(\mathrm{MHH})$ which implies that banks with undercapitalized value take more risk to take advantage of existing horizontal deposit insurance schemes. Altunbas et al. (2007) and Agusman et al. (2008) found that inefficiency is positively related with risk-taking which advocates the $\mathrm{MHH}$, i.e. banks with a low-performance level are more vulnerable than banks with a high-performance level. However, no relationship between bank capital and risk has been found by Guidara et al. (2013). By using a meanvariance approach, Kim and Santomero (1988) and Koehn and Santomero (1980) showed that single capital ratio regulation is not enough to control risk. For ignoring the option value of deposit insurance, the mean-variance is not appropriate (Keeley and Furlong, 1990; Furlong and Keeley, 1989). They used a contingent-claims model and showed that enlarged capital would not raise portfolio risk of banks. The reason behind this is that the value of the deposit insurance reduces as the capital increases. Table II summarizes the prior literature.

\subsection{Literature related to variables used under the study}

2.3.1 Bank performance variable. Prior literature uses various measures of performance such as return on assets (ROA), return on equity (ROE), net interest margin, earning per share, Tobin's Q, etc. Previous literature also indicates that performance measures can be calculated in various ways. For example, ROA can be calculated by considering before tax profit, or after-tax profit, or total assets, or average total assets, or total earning assets or average earning assets. This study uses ROA before tax as a measure of performance by following the study of Tan (2016), Demirgüç-Kunt and Huizinga (1999) and others.

2.3.2 Bank risk variables. This study uses three types of risk, namely default risk, credit risk and overall risk. The study measures default risk by following the study of Iannotta et al. (2007), where they measure default risk using natural logarithm of $Z$-score. The $Z$-score is used by a number of empirical studies as the risk or stability indicator in the banking sector (Liu and Wilson, 2013; Liu et al., 2013; Tan, 2016) and it is calculated by using the sum of a bank's ROA and equity to total assets ratio (ETAR) over the standard deviation of the bank's ROA. A higher Z-score indicates that there is a higher stability and lower risk (Tan, 2016). By following (Agoraki et al., 2011), the study measures credit risk by the nonperforming loans to total loans. The higher non-performing loans to total loans ratio indicate that there is more risk for losses from loans defaults (Zhang et al., 2013). This investigation also measures overall risk by the loan loss provision to net interest revenue ratio, used by Baselga-Pascual et al. (2015).

2.3.3 Bank capital variables. This study uses two types of capital measures:

(1) the traditional non-risk-based capital (total shareholders' ETAR) which is known as actual capital; and

(2) the risk-based capital (capital adequacy ratio [CAR]) which is known as regulatory capital.

Many prior empirical studies use non-risk-based capital (Shrieves and Dahl, 1992; Altunbas et al., 2007; Lee and Hsieh, 2013; Tan and Floros, 2013; Iannotta et al., 2007; Sufian and Habibullah, 2009; Sufian, 2012; Amidu and Hinson, 2006; Athanasoglou et al., 2008; Dietrich and Wanzenried, 2011). Many studies use regulatory capital measures (Aggarwal and Jacques, 2001; Jacques and Nigro, 1997; Ediz et al., 1998). 
JEFAS
23,46

206

Table II.

Literature on the linkage between bank Capital and risk

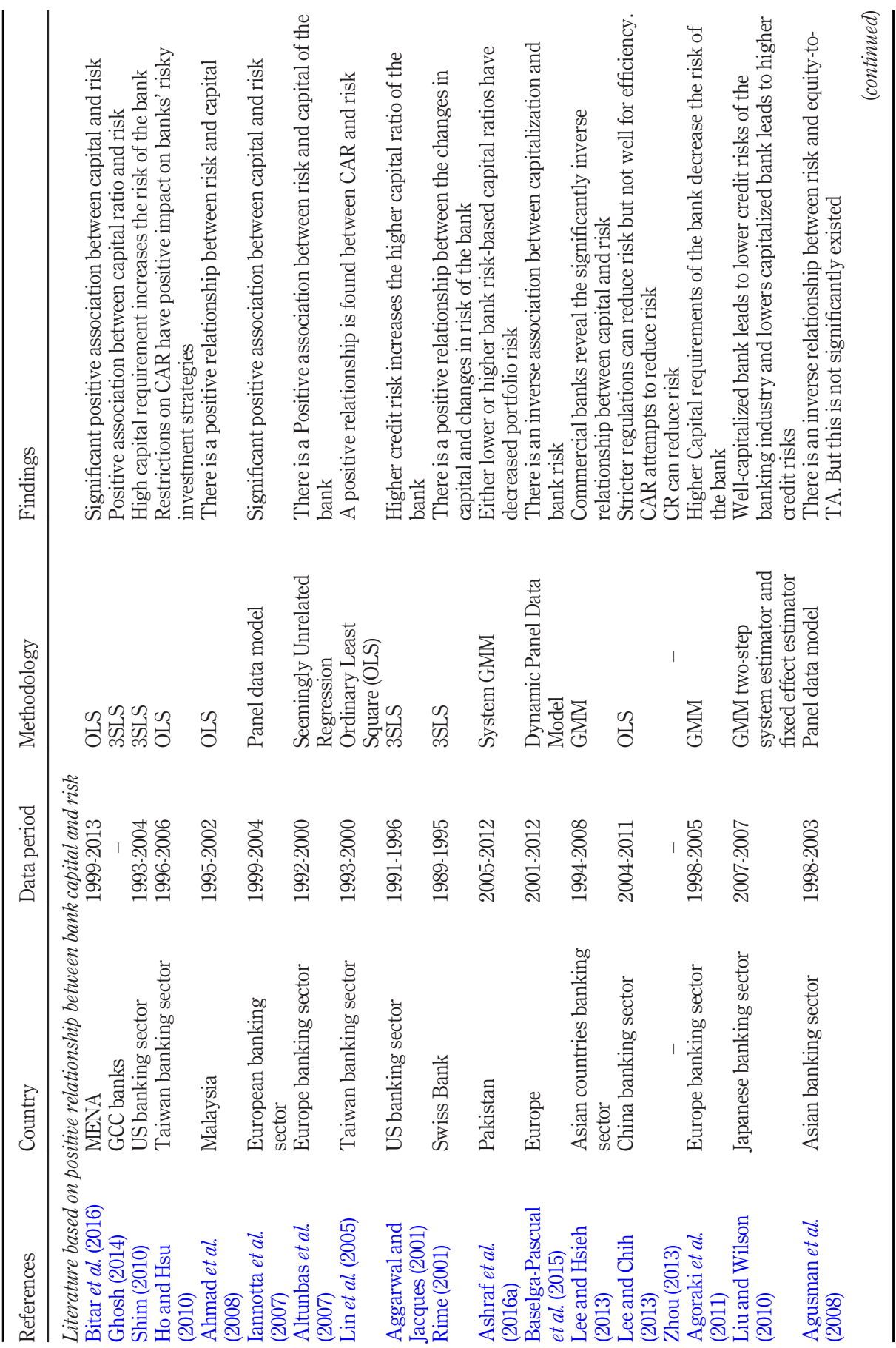




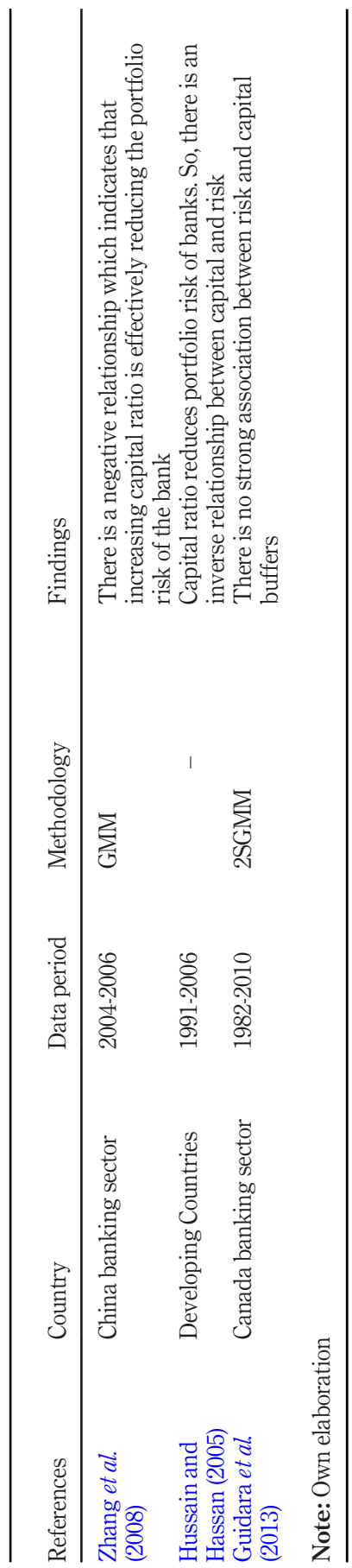

Bank risk and performance

207

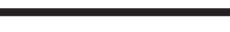

Table II. 
JEFAS

23,46

\subsubsection{Bank-specific control variables}

2.3.4.1 Liquidity. This study uses the ratio of total loans to total assets as a measurement of liquidity in the performance equation by following the study of Goddard et al. (2013). The largest ratio indicates a lower level of liquidity. Thus, a large amount of loans to the customer indicates more interest revenue from them. Hence, the negative impact of liquidity on bank performance is expected. In contrast, Bourke (1989) argues that the higher liquidity level of a bank generates higher profit. The higher volume of loans sometimes leads to decline the bank performance if the bank does not have a good risk management system. Therefore, it is expected that there may be a positive or negative impact of liquidity on bank performance.

2.3.4.2 Cost inefficiency. The study uses operating expenses to total assets as cost inefficiency measurements by following the study of Dietrich and Wanzenried (2011). These measures have been used extensively in the existing literature (Liu and Wilson, 2010; Kosmidou, 2008; García-Herrero et al., 2009). The existing literature shows mixed results. For example, Molyneux and Thornton (1992) find the positive impact of cost inefficiency on bank performance. Naceur (2003) also find a positive relationship between cost inefficiency and bank performance in the Tunisian banking industry. The positive relationship between cost inefficiency and performance also supports the efficiency wage theory. The existing literature also indicates that there is a negative relationship between cost inefficiency and bank performance. For example, Athanasoglou et al. (2008) claim that well-managed banks have the ability to reduce operating costs, which in turn increases bank performance. This opinion is supported by the study of Bourke (1989) and Jiang et al. (2003a). Therefore, it is expected that there may be a positive or negative impact of cost inefficiency on bank performance.

The prior literature indicates cost inefficiency is a source of risk (Poghosyan and Čihak, 2011; Männasoo and Mayes, 2009). Louzis et al. (2012), in their bad management hypothesis, suggest that cost inefficiency is positively associated with the increases of future nonperforming loan which ultimately leads to bad management and thus poor skills in credit scoring. Therefore, a positive relationship is expected between cost inefficiency and bank risk.

2.3.4.3 Labor productivity. This investigation uses net profit after tax over a total number of employees as a measurement of labor productivity. This variable has been widely used by the researcher in the prior literature to investigate its impact on bank performance (Tan and Floros, 2013; Tan and Floros, 2012b; Tan and Floros, 2012a, Tan and Floros, 2012c; Athanasoglou et al., 2008). The higher the labor productivity ratio indicates banks efficient management which reflects banks performance. Therefore, this study predicts a positive association with performance.

2.3.4.4 Non-traditional activity. This study uses off-balance sheet items to total assets as non-traditional activity measures. This variable has been included in the performance equation. Bank can increase their sources of income by the off-balance sheet activities without changing the capital structure which ultimately affects the performance (Apergis, 2014; Deelchand and Padgett, 2009). Rahman et al. (2015) find a significant negative association between non-traditional activity and bank profitability. Hence, no prior expectation of this variable.

2.3.4.5 Income diversification. The study uses the ratio of non-interest income to total income as a measure of income diversification. A bank engaged in different types of businesses is able to generate more income (Tan and Floros, 2012b). In addition, the more diversified banks can reduce their costs easily from economies of scope. Jiang et al. (2003b) find a positive association between income diversification and performance. However, 
others find (Demirgüç-Kunt and Huizinga, 1999; Gischer and Jüttner, 2001) negative association of income diversification with performance because there is stronger competition to generating free income compared to traditional interest income activity which ultimately reduces bank performance. Thus, the study finds mixed results and no prior expectation regarding the relationship between income diversification and performance.

2.3.4.6 Deposit ratio. This study includes deposit ratio in the risk equation and total deposit to total assets has considered as a measure of deposit ratio. As deposits are insured, a higher deposit ratio raises moral hazard of banks to fund in risky investments (Soedarmono et al., 2010). In addition, the higher deposit ratio increases leverage risk. Therefore, a positive relation is predicted between deposit ratio and bank risk.

2.3.4.7 Leverage. This study uses total liabilities to total assets as a measure of leverage and includes this variable in the risk equation. Higher leverage may be both beneficial and cost to the banks. For example, the high leverage ratio indicates more debt in the capital structure which indicates higher interest payments and thus create pressure on the bank income (Zheng et al., 2017), as well as increase risk. On the other hand, the higher leverage may increase profit by reducing risk because interest payments provide a tax shield. Chaibi and Ftiti (2015) claim that risk is affected by capital structure. Highly leveraged capital leads to a tendency to a higher risk-taking because of the need to produce higher returns with lower capital. Thus, no prior expectation of this variable on the impact of bank risk.

\subsubsection{Industry and macro-economic variables}

2.3.5.1 Market power. This study used concentration ratio as a measure of market power and included in the performance equation. According to structure conduct performance (SCP) hypothesis, the banks' behavior is affected by market power, while the market structure plays a decisive role in bank performance. The idea of this hypothesis is based on the fact that in a more concentrated market where significant shares are occupied by a few banks, the competitive condition is lower, while higher concentration leads to greater market power, and the resultant increase in the collusive behavior leads to higher profits. These indicators were recently used by (Fu et al., 2014; Al-Muharrami et al., 2006) to measure competition in the banking industry.

2.3.5.2 Economic growth. The study measures economic growth by the annual GDP growth rate. Because of increasing the demand for lending during the cyclical upswings, some researchers claims GDP growth rate has a positive impact on the bank performance (Athanasoglou et al., 2008; Bikker and Haaf, 2002; Demirgüç-Kunt and Huizinga, 1999). However, Tan and Floros (2012a) investigate the association between GDP growth and bank profitability in China and finds a negative association between both variables. They argue that the economic growth improves the environment of the business, and which lowers the entry barriers of banks. As a result, the competition increased dampens the performance of banks. Thus, this study has no prior expectation regarding this variable.

2.3.5.3 Bank lending interest rate. This study uses a bank lending interest rate variable in the risk equation. Geng et al. (2016) examine the effects of the interest rates on bank risk in China by using the ratio of interest income to total loans as a measure of lending interest rate. Their findings indicate the lower level of bank lending interest shows lower interest income from loans, which causes reduction of bank earnings. They also claim that the low lending interest rate shows that some loans fail to be recovered and become non-performing loans, which causes an increasing risk. Therefore, to achieve the target profit, banks have to invest in high risky projects or financial instruments. Hence, the study expects a negative relation between bank lending interest rate and bank risk. 
JEFAS 23,46

210
2.3.5.4 Inflation. This study uses annual inflation rate to see the effect of it on the bank risk. Arpa et al. (2001) argue that if inflation increases then the banking sector share of risk provisions in the total loans also increases. Hussain and Hassan (2005) also find a positive association between inflation and bank risk.

\section{Research methodology}

3.1 Data sources, sample, and sample characteristics

This study mainly uses secondary sources of data. As sources of data, the study uses Bankscope database (Bitar et al., 2016; Demirguc-Kunt et al., 2013). Also, to fill up the missing data, the investigation relied on the annual audited financial statement of each bank collected from the bank websites and Dhaka Stock Exchange, Bangladesh. The industry and macroeconomic data have gathered from the Bangladesh Bank website (www.bb.org. bd) and World Bank database (data.worldbank.org). The study also uses journals, books, different websites, library facility for the desk and extensive study as secondary sources of data.

To meet the desired objectives, the study has considered an unbalanced panel data of 30 sample banks of Bangladesh during the period from 2000-2015. The details about the sample have shown in Table III.

\subsection{Empirical models and specification of variables}

The study investigates the effect of risk-based capital and traditional non-risk based capital on the bank risk and performance of Bangladesh. For this purpose, the study uses two simultaneous equations by following the previous literature (Zheng et al., 2017; Tan and Floros, 2013; Vollmer and Wiese, 2013; Francis and Osborne, 2012; Fiordelisi et al., 2011; Ben Naceur and Kandil, 2009; Altunbas et al., 2007; Nier and Baumann, 2006; Lee and Hsieh, 2013; Hussain and Hassan, 2005; Ayuso et al., 2004; Jacques and Nigro, 1997) as follows:

$$
\begin{aligned}
P_{i t}= & \beta_{0}+\beta_{1} P_{i t-1}+\beta_{2} C_{i t}+\beta_{3} R_{i t}+\beta_{4} L I Q D_{i t}+\beta_{5} \text { OETA }_{i t}+\beta_{6} L P_{i t} \\
& +\beta_{7} \text { OFBSTA }_{i t}+\beta_{8} I N C D_{i t}+\beta_{9} \text { CONC3 }_{i t}+\beta_{10} G G R_{t}+\varepsilon_{i t}
\end{aligned}
$$

Panel A: Sample size

Number of banks 56

Less: banks without available information

Total banks under the study

Panel B: Category-wise distribution

State-owned commercial bank

Conventional private commercial bank

Islamic private commercial bank

2

22

Total banks under the study

30

Panel C: Bank-year observations

Bank-year observations consideration for the study: 30 banks $\times 16$ years $(2000-2015)$

Less: bank-year observations without available information

Final total bank-year observations under the study

480 bank-years 67 bank-years 413 bank-years
Table III.

Sample descriptions

Note: Author development 


$$
\begin{aligned}
R_{i t}= & \gamma_{0}+\gamma_{1} R_{i t-1}+\gamma_{2} C_{i t}+\gamma_{3} P_{i t}+\gamma_{4} O_{E T A_{i t}}+\gamma_{5} D P R_{i t}+\gamma_{6} L E V_{i t}+\gamma_{7} B L I N T_{i t} \\
& +\gamma_{8} I N F L R_{t}+\varepsilon_{i t}
\end{aligned}
$$

Bank risk and performance

In the above two equations, the subscript $i$ indicates the cross-sectional dimension across banks, $t$ refers to years and $\varepsilon_{i t}$ denotes the random error term which includes the unobserved bank-specific effect and idiosyncratic error.

The first equation uses to tests whether the performance of banks is affected by the bank capital. In the equation, $P_{i t}$ indicates bank performance using ROA before tax (ROAB); $\beta_{0}$ is the constant term; $P_{i t-1}$ is the one period lagged performance variable; $\mathrm{C}_{i t}$ is the bank capital has measured by the CAR and Total Shareholder's ETAR; $R_{i t}$ is the Bank Risk has measured by the default risk (LNZSCORE), credit risk (Non-performing loans to Total loans, NPLTL), and overall risk (Loan loss provision to Net interest revenue, LLPNIR); $L I Q D_{i t}$ is the liquidity has measured by the total loans to total assets ratio; OETA $A_{i t}$ is the cost inefficiency measures has calculated by the operating expenses to total assets ratio; $L P_{i t}$ is the labor productivity has calculated by the net profit after tax to total number of employees; $\mathrm{OFBSTA}_{i t}$ is the non-traditional activity measures by the off-balance sheet items to total assets ratio; $I N C D_{i t}$ is the income diversification has calculated by the ratio of non-interest income to total income; $C O N C 3_{i t}$ is the market power has measured by the concentration ratio of the three largest bank assets to total assets; and $G G R_{t}$ is the annual GDP rate (per cent).

The second equation uses to tests whether the risk taking the behavior of banks are affected by the bank capital. In the equation, $R_{i t}, C_{i t}$, and $P_{i t}$ indicates same meaning as defined in the first equation; $\gamma_{0}$ is the constant term; $R_{i t-1}$ is the one period lagged risk variable $\left(L N Z S C O R E_{i t-1}, N P L T L_{i t-1}, L L P N I R_{i t-1}\right) ; O E T A_{i t}$ is the cost inefficiency measures has calculated by the operating expenses to total assets ratio; $D P R_{i t}$ is the deposit ratio has measured by the total deposit to total assets ratio; $L E V_{i t}$ is the leverage has calculated by the total liabilities to total assets ratio; $B L I N T_{i t}$ is the bank lending interest rates (per cent); INFLR $R_{t}$ is the annual inflation rate (per cent).

The descriptions of the variables and their expected effects on the bank performance and risk have shown in Tables IV and V.

\subsection{Methods of data analysis}

The previous empirical literature uses a variety of methods to solve the simultaneous equation, but not all methods are appropriate for all cases. The study examines the impact of bank capital on performance and risk by using Two-Step system GMM estimator developed by Arellano and Bover (1995) and Blundell and Bond (2000). GMM estimator has applied here because some problems have faced by the simultaneous equations, namely, endogeneity issue, serial correlation and heteroscedasticity. Lee and Hsieh (2013) argue GMM technique is more effective compared to OLS technique. OLS technique provides biased results in the estimation of a dynamic model (Nickell, 1981). To be more specific, two types of variants observed in the GMM: differenced GMM estimator and system GMM estimator. The study prefers the later one compared to the previous one because the system GMM estimator provides more precise results than difference GMM by solving the critical issues. GMM has considered superior to dynamic panel model because it provides estimates of fixed effects and OLS (Bond, 2002).

To run the regression using GMM with Eviews-8, the study first tests the identification of simultaneous equation to see whether the equation is over-identified or not because it is one of 


\section{JEFAS 23,46}

\begin{tabular}{l} 
Variables \\
\hline Main variables \\
Bank \\
performance \\
Bank risk
\end{tabular}

212

\section{Bank risk}

ROAB Profit before tax as a fraction of total assets

LNZSCORE Natural logarithm of zscore; where zscore = (ROA plus the ratio of shareholders equity to total assets)/standard deviation of ROA

NPLTL It is the ratio of non-performing loans to total loans

LLPNIR The ratio of loan loss provision to net interest revenue

Bank capital

CAR

ETAR

It is the sum of tier- 1 and tier- 2 capital as a percentage of risk-weighted assets The ratio of total shareholders' equity to total assets

Bank-specific control variables

$\begin{array}{ll}\text { Liquidity } & \text { LIQD } \\ \text { Cost inefficiency } & \text { OETA }\end{array}$

The ratio of total loans to total assets

The ratio of operating expenses to total assets

\begin{tabular}{|c|c|c|}
\hline $\begin{array}{l}\text { Labor } \\
\text { productivity }\end{array}$ & LP & Net profit after tax generated by per employee \\
\hline $\begin{array}{l}\text { Non-traditional } \\
\text { activity }\end{array}$ & OFBSTA & $\begin{array}{l}\text { Off balance sheet items as a fraction of total } \\
\text { assets }\end{array}$ \\
\hline $\begin{array}{l}\text { Income } \\
\text { diversification }\end{array}$ & INCD & The ratio of non-interest income to total income \\
\hline sit ratio & DPR & Total deposit as a fraction of total assets \\
\hline age & LEV & Total liabilities to total assets ratio \\
\hline
\end{tabular}

Industry and macro-economic variables

Market power CONC3 The total assets of the largest three banks as a

$\begin{array}{ll}\text { Economic } & \text { GGR } \\ \text { Annual GDP growth rate }(\%)\end{array}$

growth

Table IV.

Interest rate

Inflation

BLINT

INFLR

Bank lending interest rate (\%)

Annual Inflation Rate (\%)
References

(Demirgüç-Kunt and Huizinga, 1999; Tan, 2016)

(Iannotta et al., 2007)

(Agoraki et al., 2011)

(Baselga-Pascual et al., 2015)

(Bitar et al., 2016)

(Zheng et al., 2017)

(Goddard et al., 2013)

(Dietrich and Wanzenried, 2011)

Author Idea

(Rahman et al., 2015)

(Tan, 2016; Majumder et al., 2018)

(Ashraf et al., 2016a)

(Doyran, 2013)

(Tan, 2016)

(Baselga-Pascual et al., 2015; Majumder and Uddin, 2017)

(Geng et al., 2016)

(Tan and Floros, 2013;

Akter et al., 2018) variables used in the study

Note: Author development

the pre-condition of using GMM. The investigation also seeks whether the models of each equation suffers from endogeneity, serial correlation and heteroscedasticity issues. For these issues, the study employs Durbin-Wu-Hausman endogeneity test, Breusch-Godfrey serial correlation LM test and white heteroscedasticity test. The study also considers Hausman test for fixed/random effect to see which is appropriate for the model. Also, to test the validity of the instruments and over-identifying restrictions the Sargan j-test applies here.

The study also provides the descriptive statistics like mean, minimum, maximum, and standard deviation value to know the depth understanding about the study variables. The Pearson's correlation provides here to confirm that the study variables have not suffered any multicollinearity issues.

Finally, this study has applied robustness checks by introducing TSLS instead of GMM to justify the findings whether the results of the two methods are consistent or not. 


\begin{tabular}{|c|c|c|c|}
\hline Variables & Bank performance & Bank risk & Bank risk and \\
\hline Bank capital (CAR, ETAR) & $+1-$ & $+1-$ & \\
\hline Bank risk (LNZSCORE, NPLTL, LLPNIR) & - & & \\
\hline Bank performance (ROAB) & & - & \\
\hline Liquidity (LIQD) & $+1-$ & & \\
\hline Cost inefficiency (OETA) & $+/-$ & + & \\
\hline Labor productivity (LP) & + & & 213 \\
\hline Non-traditional activity (OFBSTA) & $+1-$ & & \\
\hline Income diversification (INCD) & $+1-$ & & \\
\hline Deposit ratio (DPR) & & + & \\
\hline Leverage (LEV) & & + & Table V. \\
\hline Market power (CONC3) & $+1-$ & & Summary of \\
\hline Economic growth (GGR) & $+1-$ & & expected effects of \\
\hline Interest rate (BLINT) & & - & the study variables \\
\hline Inflation (INFLR) & & + & on bank performance \\
\hline Note: Author development & & & and risk \\
\hline
\end{tabular}

\section{Empirical results and discussion}

This chapter has divided into four different sections. The first section highlights the descriptive statistics of all variables of the total sample year observations. The second section provides Pearson correlation matrix among the independent variables used in the study. The third section indicates regression analysis. Finally, the fourth section provides evidence of the accuracy of study findings by the robustness check.

\subsection{Descriptive statistics}

Table VI shows the descriptive statistics of the study variables which includes the minimum value, maximum value, mean value, standard deviation value and the number of observations of the sample variables. Among the study variables, it has been observed that the bank lending interests rate (BLINT) has a greater amount of variation among the samples (standard deviation $=0.977)$ followed by economic growth $(G G R)$ with a standard deviation of 0.834 , bank risk (LNZSCORE) with a standard deviation of 0.504, and others. The only performance variable ROA before tax (ROAB) shows a mean value of 0.023 with a maximum value of 0.065 , the minimum value of 0.001 , and standard deviation of 0.010 . There is not so much variation of ROAB among the samples. Among the three risk measures of LNZSCORE, NPLTL and LLPNIR, LNZSCORE shows the greater variations among the samples indicate variations of risk or financial stability. The minimum value of NPLTL (0) indicates one or some of the sample has no non-performing loan which is a good sign and the evidence finds it for the one bank. The ratio of LLPNIR indicates a minimum value of negative figure (-1.331) which means one or some of the samples have a shortage of provision or negative net interest revenue. The average CAR (11.28 per cent) indicates higher capital adequacy has maintained by the sample banks on an average as per requirements of the BASEL II accord. But, the minimum value (5.65) indicates one or some of the banks has not maintained the minimum capital requirements of 10 per cent as per BASEL II accord. The equity to capital ratio (ETAR) indicates a mean value of 0.074 which is far from the maximum value of 0.154 and a minimum value of 0.002 . So, there is a greater deviation from the average value of ETAR. 


\begin{tabular}{|c|c|c|c|c|c|c|}
\hline \multirow{6}{*}{$\begin{array}{l}\text { JEFAS } \\
23,46\end{array}$} & Variables & Mean & Maximum & Minimum & Standard deviation & Observations \\
\hline & ROAB & 0.023 & 0.065 & 0.001 & 0.010 & 413 \\
\hline & LNZSCORE & 2.793 & 3.927 & 0.980 & 0.504 & 413 \\
\hline & NPLTL & 0.060 & 0.396 & 0.000 & 0.064 & 413 \\
\hline & LLPNIR & 0.300 & 2.413 & -1.331 & 0.309 & 413 \\
\hline & CAR & 11.280 & 24.170 & 5.650 & 2.315 & 413 \\
\hline \multirow{9}{*}{214} & ETAR & 0.074 & 0.154 & 0.002 & 0.024 & 413 \\
\hline & LIQD & 0.669 & 0.837 & 0.444 & 0.075 & 413 \\
\hline & OETA & 0.022 & 0.047 & 0.008 & 0.007 & 413 \\
\hline & $\mathrm{LP}$ & 0.608 & 2.584 & 0.008 & 0.440 & 413 \\
\hline & OFBSTA & 0.312 & 2.694 & 0.030 & 0.165 & 413 \\
\hline & INCD & 0.264 & 0.562 & 0.030 & 0.083 & 413 \\
\hline & CONC3 & 0.278 & 0.463 & 0.206 & 0.053 & 413 \\
\hline & GGR & 5.897 & 7.100 & 3.800 & 0.834 & 413 \\
\hline & DPR & 0.812 & 0.935 & 0.615 & 0.053 & 413 \\
\hline \multirow{4}{*}{$\begin{array}{l}\text { Table VI. } \\
\text { Descriptive statistics } \\
\text { of the sample } \\
\text { variables }\end{array}$} & BLINT & 12.489 & 13.940 & 10.400 & 0.977 & 413 \\
\hline & INFLR & 6.202 & 8.200 & 3.300 & 1.402 & 413 \\
\hline & LEV & 0.914 & 1.013 & 0.046 & 0.105 & 413 \\
\hline & \multicolumn{6}{|c|}{ Note: Author calculations } \\
\hline
\end{tabular}

\subsection{Correlation}

Table VII shows the degree of relationships among the independent variables used in the study. This study uses Pearson correlation matrix to examine whether any multicollinearity issues exists between independent variables.

Among the study variables, the highest correlation is 0.61 between the two capital ratios CAR and total shareholders' ETAR. Kennedy (2003) claims that the correlation value above 0.70 indicates multicollinearity problem exists between the variables. Another academician, Gujarati (2009), states that the correlation value above 0.80 between the two variables creates serious multicollinearity problem. Thus, this study indicates the correlations among the variables are not so strong, which suggest non-existence of multicollinearity issues.

\subsection{Regression}

4.3.1 The impact of bank capital on performance. Table VIII reports the empirical results of the equation one where six model uses for the regression analysis. The table provides the impact of bank capital on the performance of the Bangladeshi banking sector. The first three models (1-3) depict the simultaneous effect of bank capital (CAR) and risk (default risk, LNZSCORE; credit risk, NPLTL; and overall risk, LLPNIR) on the bank performance (ROA before tax, ROAB) of Bangladesh. The second three models (4-6) show the simultaneous effect of bank capital (ETAR) and risk (default risk, LNZSCORE; credit risk, NPLTL; and overall risk, LLPNIR) on the bank performance (ROA before tax, ROAB) of Bangladesh. The regression findings indicate that the lag dependent variable $\left(\mathrm{ROAB}_{\mathrm{t}-1}\right)$ is positively and statistically significant with the performance across all the six models. Thus, it is evidence that there is a persistence of performance from one year to next year. The study highlights that the main independent variable bank capital (CAR; and ETAR) has a significant and positive impact on bank performance (ROAB) using all the three types of risk measures across all the six models. Thus, the higher the capital ratio indicates higher the bank performance. The findings of the study are in line with Psillaki and Mamatzakis (2017), Zheng et al. (2017), Casu et al. (2017), Bougatef and Mgadmi (2016), Lee and Hsieh (2013), 


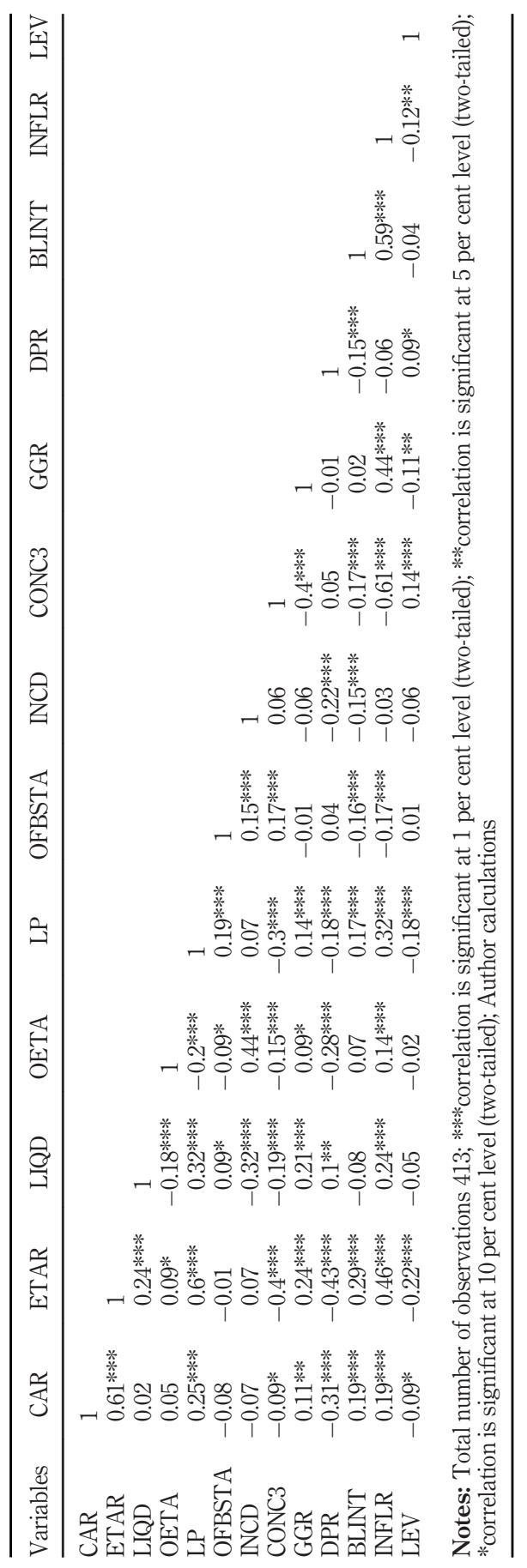

Bank risk and performance 
JEFAS

23,46

216

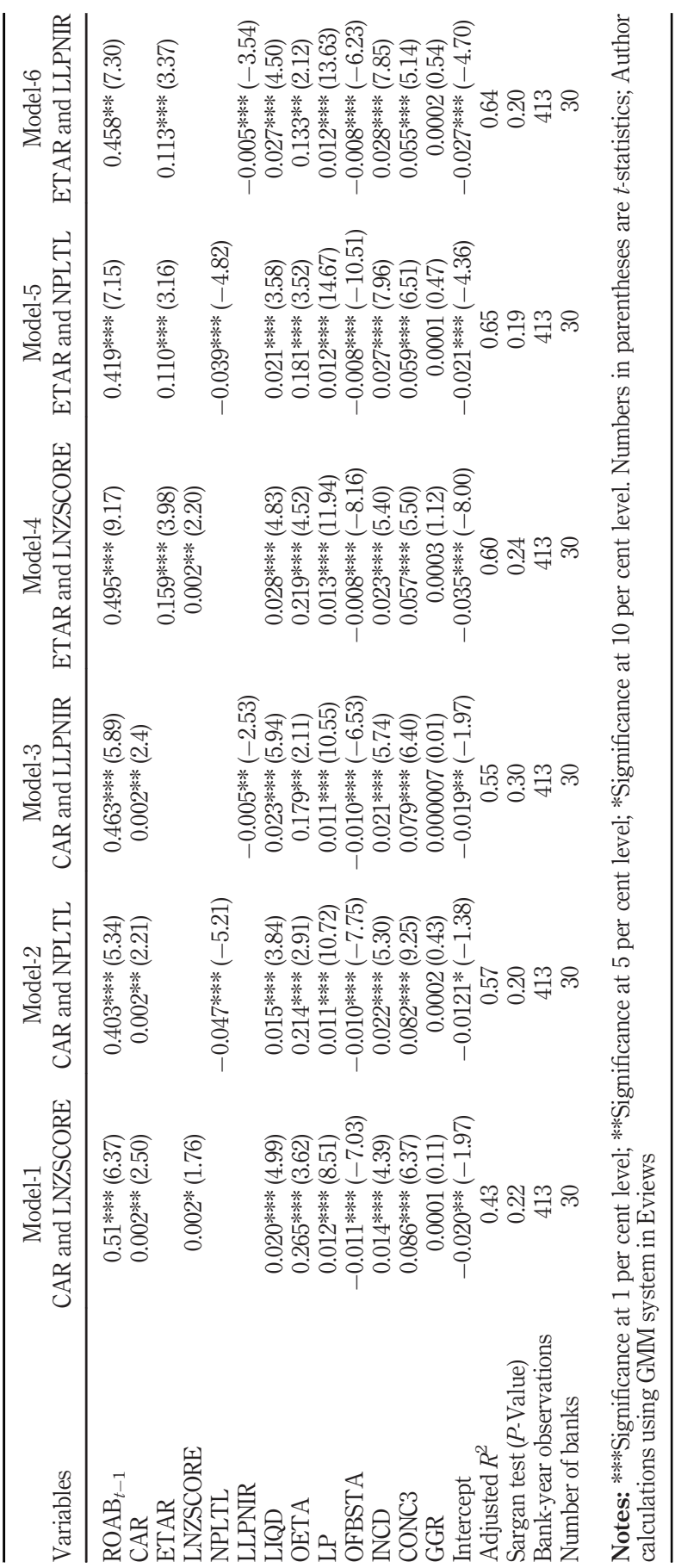

Table VIII.

The impact of bank capital on performance 
Mbizi (2012), Naceur and Omran (2011), Ben Naceur and Kandil (2009), Pasiouras and Kosmidou (2007), Lin et al. (2005), Goddard et al. (2004), Rime (2001) and Jacques and Nigro (1997). The findings are inconsistent with the views that higher capital requires higher opportunity cost of holding and thus jeopardize the performance of the banks (Goddard et al., 2013; Karels et al., 1989; Brewer III and Lee, 1986). The study finds that all the three measures of risk across the six models indicate a negative impact on bank performance. Among all control variables, all the variables significantly affect the bank performance except economic growth (annual GDP growth rate, GGR). The study includes this variable as excluding it weaken the model. The study finds liquidity ratio (LIQD) is positively and significantly impact on bank performance. Higher liquidity ratio indicates a lower level of liquidity. Thus, the study finds a negative relationship of liquidity with a performance which indicates higher the loans leads to higher interest revenue and improve bank performance. The result is consistent with the findings of Molyneux and Thornton (1992) and Goddard et al. (2013); it is inconsistent with Bourke (1989). Cost inefficiency (OETA), i.e. the ratio of operating expenses to total assets, is positively and significantly affects the bank performance which means more expenditure on salary, wages to the staff increases their productivity and thus performance increases. The findings have supported the efficiency wage theory (Tan, 2016) and also consistent with the findings of Naceur (2003) and Molyneux and Thornton (1992). However, the negative impact of cost inefficiency on performance has found by Dietrich and Wanzenried (2011), Athanasoglou et al. (2008) and Bourke (1989). Labor productivity is positively and significantly impact on bank performance. The higher level of labor productivity indicates a higher level of bank efficiency and which leads to higher profit. The findings are supported by the study of Zheng et al. (2017). The non-traditional activity (off balance sheet items to total assets, OFBSTA) implies negative and significant impact on profitability which means as off balance sheet items increases then performance decreases. The results is consistent with Rahman et al. (2015), but the findings of Apergis (2014) has found positive impact of nontraditional activity on bank performance. This study finds that income diversification (INCD) has a significant and positive impact on performance which indicates the more diversified of a bank faces less risk and increases performance. The findings are consistent with Jiang et al. (2003b), but opposite of the findings of Tan (2016), Gischer and Jüttner (2001) and Demirgüç-Kunt and Huizinga (1999). The findings of this study provide that Market power (CONC3) i.e. the concentration ratio is positively and significantly impact on the bank performance which supports the market SCP hypothesis (Tan, 2016).

4.3.2 The impact of bank capital on risk. Table IX reports the empirical results of the equation two where six model uses for the regression analysis. Table IX provides the impact of bank capital on the risk of the Bangladeshi banking sector. The first three models (1-3) depict the simultaneous effect of bank capital (CAR) and performance (ROA before tax, ROAB) on three measures of risk (default risk, LNZSCORE; credit risk, NPLTL; and overall risk, LLPNIR). The second three models (4-6) show the simultaneous effect of bank capital (ETAR) and performance (ROA before tax, ROAB) on three measures of risk (default risk, LNZSCORE; credit risk, NPLTL; and overall risk, LLPNIR).

The regression findings indicate that the lag dependent variable $\left(\mathrm{LNZSCORE}_{\mathrm{t}-1}\right.$, $\left.\mathrm{NPLTL}_{\mathrm{t}-1}, \mathrm{LLPNIR}_{\mathrm{t}-1}\right)$ is positively and statistically significant with the risk across all the six models. Thus, it is evidence that there is a persistence of risk from one year to next year.

The study highlights that the main independent variable bank capital (CAR) has a significant and negative impact on bank risk using all the three types of risk measures across the first three models (1-3). Thus, the higher the CAR indicates lower the bank risk. The findings of the study are in line with Soedarmono and Tarazi (2016), Lee and Chih
Bank risk and performance

217 
JEFAS
23,46

218
Table IX.

The impact of bank capital on risk

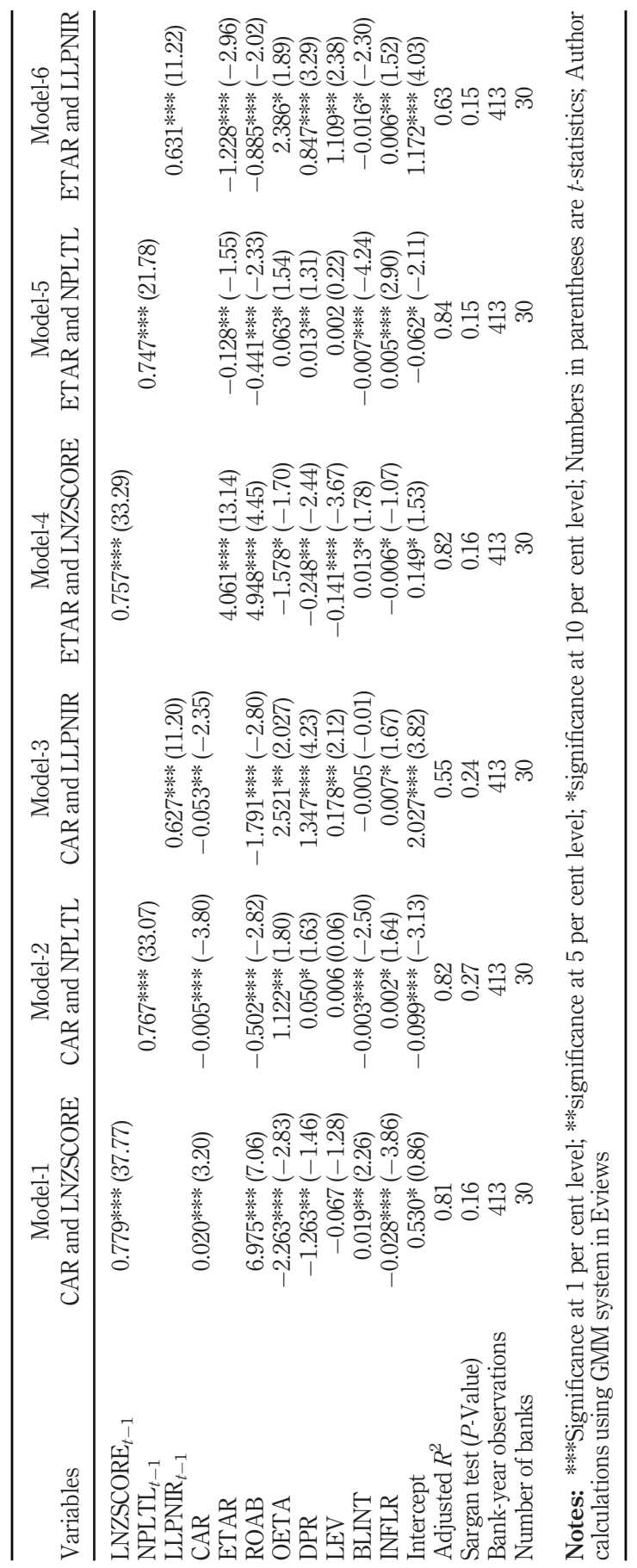


(2013), Agoraki et al. (2011), Zhang et al. (2008), Hussain and Hassan (2005), Jacques and Nigro (1997). The findings are contrary to the studies of Bitar et al. (2016), Lin et al. (2013), Altunbas et al. (2007), Lin et al. (2005), Bichsel and Blum (2004), Rime (2001), Blum (1999) and Shrieves and Dahl (1992).

The shareholder's ETAR is negatively and significantly impact on bank risk using all the three types of risk measures across the last three models (4-6). This result indicates the higher the capital ratio tends to lower the risk. This finding is supported by the studies of Bougatef and Mgadmi (2016), Hao and Zheng (2016) and Tan and Floros (2013). However, the positive relationship between ETAR and bank risk finds by the study of Bitar et al. (2016).

The study also provides evidence that bank performance negatively and significantly affects the bank's risk taking behavior across all models, which indicate that the higher the performance of a bank, the lower the risk and vice-versa.

Among the control variables, cost inefficiency (OETA) is positively and significantly impact on risk across all the models which indicate higher the operating expenses leads to high risk. The findings are consistent with the study of Baselga-Pascual et al. (2015). Deposit (DPR) is positively and significantly affects the risk across all the models which indicate higher the deposit leads to higher risk. This result is supported by the study of Ashraf et al. (2016a) and Soedarmono and Tarazi (2016). Leverage (LEV) is positively and significantly impact on risk across the models three, four, and six which indicates the higher the liabilities leads to higher risk. Bank lending interest (BLINT) is significantly and negatively associated with risk except for model-3 which means higher the percentage of lending rate lower the risk. This result supported by the study of Geng et al. (2016). The findings indicate that annual inflation rate (INFLR) has a positive and significant impact on bank risk across all the models which mean that as the rate of inflation increases in an economy, the risk also increases. The result is consistent with the findings of Arpa et al. (2001), but Tan and Floros (2013) have found an insignificant negative impact of inflation on bank risk.

\subsection{Robustness checks}

Robustness checking indicates check the robustness of the main study findings by using different techniques such as changing the dependent variable with an alternative measure, changing the methods of regression analysis, changing the alternatives control variables. In this study, I have used 2SLS methods instead of GMM to check the results effectiveness. Table $\mathrm{X}$ shows the robust results of the impact of bank capital on performance using 2SLS with random effects model. The robust finding of the study indicates that all of the variables are significant except GGR. Table XI shows the impact of bank capital on risk using the 2SLS methods with random effects. The study finds that all the variables are significant and the results largely remain same with the main findings.

\section{Conclusions}

\subsection{Summary of the findings}

After the implementation of BASEL I, BASEL II and BASEL III in the international arena, the empirical research on Bangladesh failure to give the answers to the following questions: What is the impact of bank capital on the bank performance? andWhat is the impact of bank capital on the bank risk taking behavior? To the best of my knowledge, little attention has given by the researcher to give the answer of these questions on Bangladesh. Thus, to search the answer of the above questions, this study will be a complement study of other studies and add value to the existing literature.

\section{Bank risk and performance}


JEFAS

23,46

220

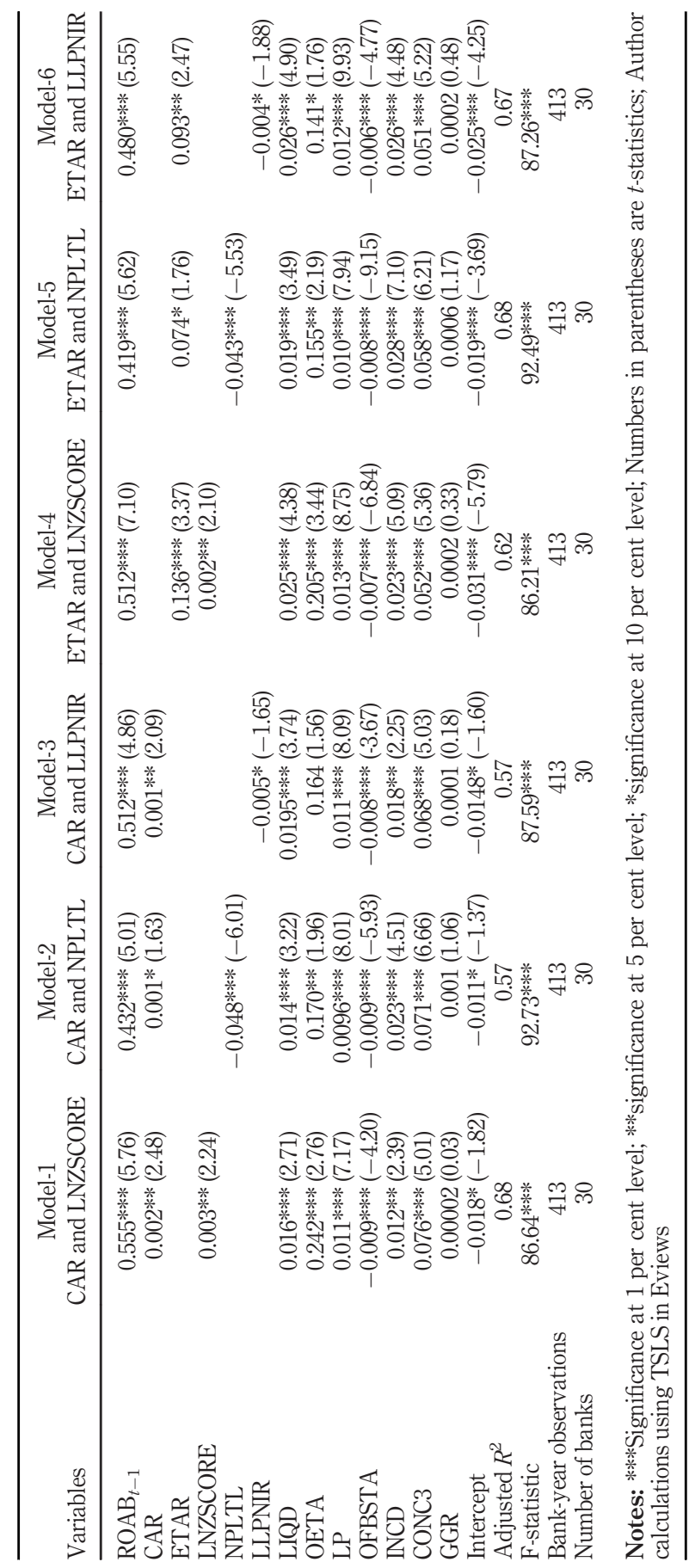

Table X.

The impact of bank capital on performance 


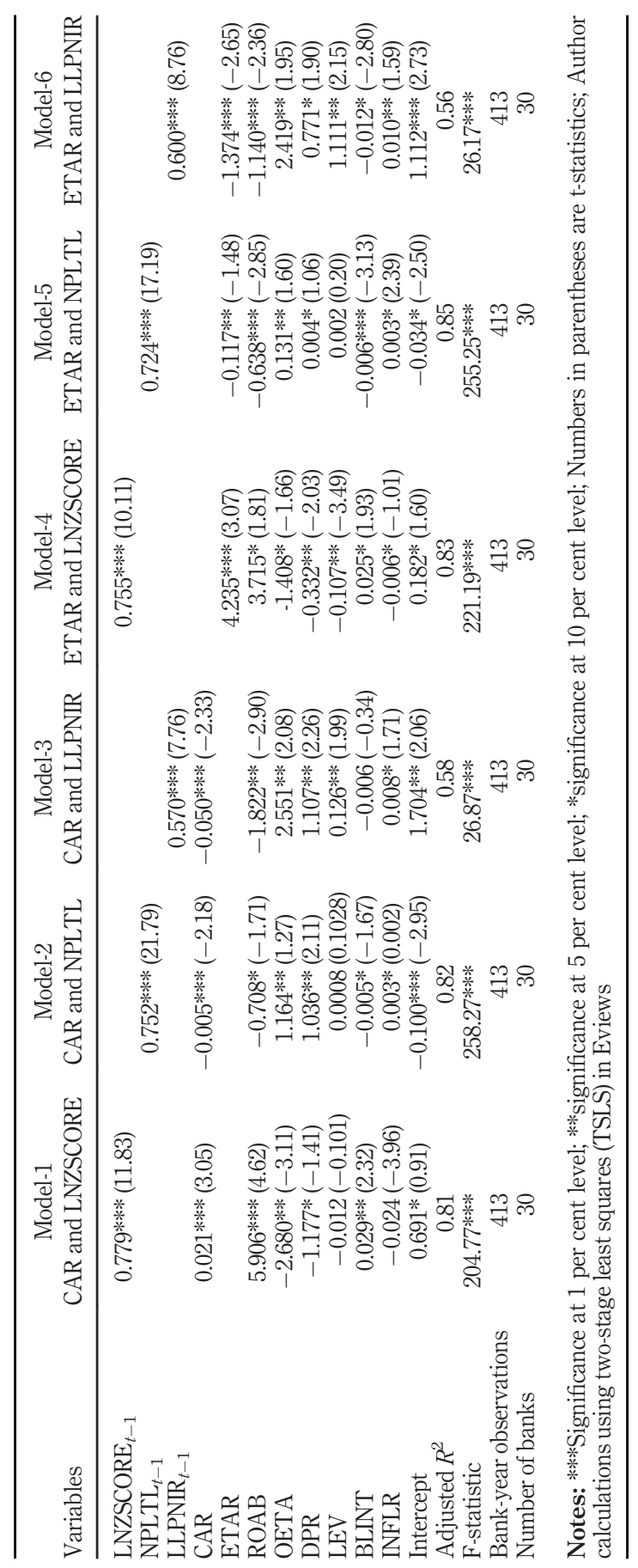

Bank risk and performance

221

Table XI.

The impact of bank capital on risk 
JEFAS 23,46

This paper examines whether bank capital affects to the bank performance and risk of Bangladeshi Banking Sector. To achieve the predetermined objectives, the study uses an unbalanced panel data set of 30 banks from 2000 to 2015 yielding 413 bank-year observations. The study has considered two capital measures of bank, namely, CAR and total shareholder's ETAR; ROA before tax has considered as performance measurement tools; three measures of risk such as default risk (natural logarithm of score), credit risk (non-performing loans to total loans) and overall risk (loan loss provision to net interest revenue) have been considered. The study also has considered some bank control measures, and industry and macro-economic factors to see the effect of those factors on capital. Liquidity ratio, cost inefficiency, labor productivity, off-balance sheet items to total assets ratio, income diversification, market power (concentration ratio) and economic growth (annual GDP growth rate) have been considered as significant determinants of bank performance. Bank cost inefficiency, deposit ratio, leverage, bank lending interest rates and the annual inflation rate has considered detecting the effect of those factors on bank risk. Using two-step system GMM, the regression analysis results solve the endogeneity issues, serial correlation problems, heteroscedasticity issues and other unobserved bank-specific issues. The study findings suggest that bank capital is positively and significantly affect the bank performance which means the higher the capital of a bank leads to higher performance. The regression results also indicate that bank capital has a significant and negative impact on bank risk which means the higher capitalized banks have a lower risk. The study also has observed that the simultaneous result indicates a significant and negative impact of risk on performance and vice-versa. Among the bank control, and industry and macroeconomic factors, cost inefficiency, labor productivity, income diversification and market power have significant and positive impact on bank performance. Bank off balance sheet items and liquidity also significantly affect the performance, but the study has found a negative impact on performance. The study has not found any significant impact of economic growth, i.e. annual GDP growth rate on bank performance. The regression result also displays that cost inefficiency, deposit ratio, leverage and the annual inflation rate is positively and significantly impact on bank risk. Bank lending interest rate also has a significant impact on bank risk but has a negative impact on risk. This investigation has also found that some of the state-owned banks were not maintained minimum capital requirements as per BASEL Capital Accord, and not maintained enough provisions against bank risk exposures.

\subsection{Recommendations and policy implications}

The main objectives of introducing the BASEL Capital Accord I, II and III are to strengthen the bank capital position to maintain financial stability through reducing risk and improving performance. This investigation also aims whether this study supports with the objective of BASEL regulations. The study finds that capital is a significant and positive factor for the bank performance and reduces bank risk of Bangladesh which supports the initiatives of BASEL regulations as well as the Central Bank of Bangladesh policy decisions to implement the BASEL guidelines. Thus, the study suggests implementing the BASEL III as soon as possible. As the higher capital ratio increases performance and reduces risk, so the banks of Bangladesh should maintain the minimum capital requirements as per BASEL guidelines and Bangladesh Bank should have to set strict decision to follow the BASEL requirements. Cost inefficiency (Operating expenses), labor productivity and income diversification significantly and positively affect the bank performance. Thus, the bank policy maker should consider those factors properly. Liquidity also significantly and negatively impact on performance which indicates more loans to customers more profit 
generation but at the same time bank should aware about the ability and project selection of the customer. The study finds a significant negative relation of off-balance sheet items on bank performance, so, the bank should be aware of off-balance sheet items. Specially, the Government of Bangladesh should give more attention to the state-owned banks properly, as this investigation finds those banks were not maintained capital adequacy properly and also faces negative net revenue and negative provisions against loans. The government also should take necessary steps to reduce inflation, as the study finds a significant and positive correlation between inflation and bank risk. Each bank should report the capital adequacy as per BASEL requirements and should also measure and report the different measures of risk and performance results in the annual report. Finally, the study suggests that higher capital ratio leads to a bank to set up careful investment strategies through reducing risk and improving performance.

\subsection{Direction for future research}

Although this study is the unique study for examining the impact of bank capital on bank performance and risk, the study faces limitations as well. The future researcher may consider the following avenues for the further study by considering the limitations of this study: first, this study has considered 30 sample banks on Bangladesh; the future researcher may consider more sample banks. Second, this study has taken data during 2000-2015, in future the latest data period may consider. Third, this investigation has been done only on one country named Bangladesh; the future researcher may include other countries which are similar nature of economic and political conditions like South Asian or African countries. Fourth, the study has considered one measure of performance, two measures of capital, and three measures of risk; in future, other measures of performance such as ROA after tax, return on average assets, return on average earning assets, ROE, NIM, earnings per share, Tobin's Q, etc. may be considered. The future researcher may also consider other capital measures such as tier-1 capital to risk-weighted assets, tier-2 capital to risk-weighted assets besides total regulatory capital to risk-weighted assets. The other measures of risk such as market risk, liquidity risk may consider in future. Fifth, the future studies may include more bank-specific, industry and macro-economic factors besides this study such as taxation, cost of intermediation, management efficiency, reserve, bank size, unemployment rate, Herfindahl index of industry concentration and revenue diversification, Lerner index of industry competition, banking sector development measure, stock market development measure, etc. Sixth, this investigation includes three main variables capital, risk, and performance; in future efficiency, competition, politics and globalization factors may add as main variable. Finally, this study has used GMM and TSLS with Eviews software for the regression analysis; in future, other best-fit methods with the best software may consider. Also, regardless of limitations, this investigation predicts that the empirical findings of this study will be beneficial for the future researcher and policymaker to develop the theory on the link between bank capital, risk and performance.

\section{References}

Aggarwal, R. and Jacques, K.T. (2001), "The impact of FDICIA and prompt corrective action on bank Capital and risk: Estimates using a simultaneous equations model", Journal of Banking and Finance, Vol. 25 No. 6, pp. 1139-1160.

Agoraki, M.E.K., Delis, M.D. and Pasiouras, F. (2011), "Regulations, competition and bank risk-taking in transition countries", Journal of Financial Stability, Vol. 7 No. 1, pp. 38-48.

\section{Bank risk and performance}

223 
JEFAS 23,46

Agusman, A., Monroe, G.S., Gasbarro, D. and Zumwalt, J.K. (2008), “Accounting and Capital market measures of risk: evidence from asian banks during 1998-2003”, Journal of Banking and Finance, Vol. 32 No. 4, pp. 480-488.

Ahmad, R., Ariff, M. and Skully, M.J. (2008), "The determinants of bank Capital ratios in a developing economy", Asia-Pacific Financial Markets, Vol. 15 Nos 3/4, pp. 255-272.

Akter, A., Majumder, M.T.H. and Uddin, M.J. (2018), "Do capital regulations and risk-taking behavior affect bank performance? Evidence from Bangladesh", Asian Economic and Financial Review, Vol. 8 No. 8, pp. 1042-1074.

Al-Muharrami, S., Matthews, K. and Khabari, Y. (2006), "Market structure and competitive conditions in the arab GCC banking system", Journal of Banking and Finance, Vol. 30 No. 12 , pp. 3487-3501.

Altunbas, Y., Carbo, S., Gardener, E.P. and Molyneux, P. (2007), "Examining the relationships between Capital, risk and efficiency in european banking", European Financial Management, Vol. 13 No. 1, pp. 49-70.

Amidu, M. and Hinson, R. (2006), "Credit risk, Capital structure and lending decisions of banks in Ghana”, Banks and Bank Systems, Vol. 1 No. 1, pp. 93-101.

Anginer, D. and Demirgüç-Kunt, A. (2014), Bank Capital and Systemic Stability, World Bank.

Apergis, N. (2014), "The long-term role of non-traditional banking in profitability and risk profiles: evidence from a panel of US banking institutions", Journal of International Money and Finance, Vol. 45, pp. 61-73.

Arellano, M. and Bover, O. (1995), "Another look at the instrumental variable estimation of errorcomponents models", Journal of Econometrics, Vol. 68 No. 1, pp. 29-51.

Arpa, M., Giulini, I., Ittner, A. and Pauer, F. (2001), "The influence of macroeconomic developments on Austrian banks: implications for banking supervision", Bis Papers, Vol. 1, pp. 91-116.

Ashraf, B.N. (2017), "Political institutions and bank risk-taking behavior", Journal of Financial Stability, Vol. 29, pp. 13-35.

Ashraf, B.N., Arshad, S. and Hu, Y. (2016a), "Capital regulation and bank risk-taking behavior: evidence from Pakistan", International Journal of Financial Studies, Vol. 4 No. 3, p. 16.

Ashraf, B.N., Zheng, C. and Arshad, S. (2016b), "Effects of national culture on bank risk-taking behavior", Research in International Business and Finance, Vol. 37, pp. 309-326.

Athanasoglou, P.P., Brissimis, S.N. and Delis, M.D. (2008), "Bank-specific, industry-specific and macroeconomic determinants of bank profitability", Journal of International Financial Markets, Institutions and Money, Vol. 18 No. 2, pp. 121-136.

Ayuso, J., Pérez, D. and Saurina, J. (2004), "Are Capital buffers pro-cyclical? Evidence from spanish panel data", Journal of Financial Intermediation, Vol. 13 No. 2, pp. 249-264.

Baselga-Pascual, L., Trujillo-Ponce, A. and Cardone-Riportella, C. (2015), "Factors influencing bank risk in Europe: evidence from the financial crisis", The North American Journal of Economics and Finance, Vol. 34, pp. 138-166.

Bennaceur, S. and Goaied, M. (2008), "The determinants of commercial bank interest margin and profitability: evidence from Tunisia", Frontiers in Finance and Economics, Vol. 5 No. 1, pp. 106-130.

Ben Naceur, S. and Kandil, M. (2009), "The impact of Capital requirements on banks' cost of intermediation and performance: the case of Egypt", Journal of Economics and Business, Vol. 61 No. 1, pp. 70-89.

Berger, A.N. and Bouwman, C.H. (2013), "How does Capital affect bank performance during financial crises?", Journal of Financial Economics, Vol. 109 No. 1, pp. 146-176.

Bichsel, R. and Blum, J. (2004), "The relationship between risk and Capital in swiss commercial banks: a panel study", Applied Financial Economics, Vol. 14 No. 8, pp. 591-597. 
Bikker, J.A. and Haaf, K. (2002), "Competition, concentration and their relationship: an empirical analysis of the banking industry", Journal of Banking and Finance, Vol. 26 No. 11, pp. 2191-2214.

Bitar, M., Saad, W. and Benlemlih, M. (2016), "Bank risk and performance in the MENA region: the importance of Capital requirements", Economic Systems, Vol. 40 No. 3, pp. 398-421.

Blum, J. (1999), "Do Capital adequacy requirements reduce risks in banking?", Journal of Banking and Finance, Vol. 23 No. 5, pp. 755-771.

Blundell, R. and Bond, S. (2000), "GMM estimation with persistent panel data: an application to production functions", Econometric Reviews, Vol. 19 No. 3, pp. 321-340.

Bond, S.R. (2002), "Dynamic panel data models: a guide to micro data methods and practice", Portuguese Economic Journal, Vol. 1 No. 2, pp. 141-162.

Bougatef, K. and Mgadmi, N. (2016), "The impact of prudential regulation on bank Capital and risktaking: the case of MENA countries", The Spanish Review of Financial Economics, Vol. 14 No. 2, pp. 51-56.

Bourke, P. (1989), "Concentration and other determinants of bank profitability in Europe, North america and Australia", Journal of Banking and Finance, Vol. 13 No. 1, pp. 65-79.

Brewer III, E. and Lee, C.F. (1986), How the Market Judges Bank Risk, Federal Reserve Bank of Chicago Economic Perspectives, Vol. 10 No. 6, pp. 25-31.

Casu, B., Deng, B. and Ferrari, A. (2017), "Post-crisis regulatory reforms and bank performance: lessons from Asia", The European Journal of Finance, Vol. 23 No. 15, pp. 1544-1571.

Cathcart, L., El-Jahel, L. and Jabbour, R. (2015), "Can regulators allow banks to set their own Capital ratios?”, Journal of Banking and Finance, Vol. 53, pp. 112-123.

Chaibi, H. and Ftiti, Z. (2015), "Credit risk determinants: evidence from a cross-country study”, Research in International Business and Finance, Vol. 33, pp. 1-16.

Chiuri, M.C., Ferri, G. and Majnoni, G. (2002), "The macroeconomic impact of bank Capital requirements in emerging economies: past evidence to assess the future", Journal of Banking and Finance, Vol. 26 No. 5, pp. 881-904.

Deelchand, T. and Padgett, C. (2009), "The relationship between risk, capital and efficiency: evidence from Japanese cooperative banks", Henley Business School, Reading University.

Deesomsak, R., Paudyal, K. and Pescetto, G. (2004), "The determinants of Capital structure: evidence from the asia pacific region”, Journal of Multinational Financial Management, Vol. 14 Nos 4/5, pp. 387-405.

Demirgüç-Kunt, A. and Huizinga, H. (1999), "Determinants of commercial bank interest margins and profitability: some international evidence", The World Bank Economic Review, Vol. 13 No. 2, pp. 379-408.

Demirgüç-Kunt, A. and Huizinga, H. (2000), "Financial structure and bank profitability".

Demirgüç-Kunt, A. and Kane, E.J. (2002), "Deposit insurance around the globe: where does it work?”, The Journal of Economic Perspectives, Vol. 16, pp. 175-195.

Demirguc-Kunt, A., Detragiache, E. and Merrouche, O. (2013), "Bank Capital: lessons from the financial crisis", Journal of Money, Credit and Banking, Vol. 45 No. 6, pp. 1147-1164.

Dermine, J. (2015), "Basel III leverage ratio requirement and the probability of bank runs", Journal of Banking and Finance, Vol. 53, pp. 266-277.

Dietrich, A. and Wanzenried, G. (2011), "Determinants of bank profitability before and during the crisis: evidence from Switzerland", Journal of International Financial Markets, Institutions and Money, Vol. 21 No. 3, pp. 307-327.

Doyran, M.A. (2013), "Net interest margins and firm performance in developing countries: evidence from argentine commercial banks", Management Research Review, Vol. 36, pp. 720-742.

Ediz, T. Michael, I. and Perraudin, W. (1998), "The impact of capital requirements on UK bank behaviour", Economic Policy Review, October, pp. 15-22. 
JEFAS 23,46

Fiordelisi, F., Márquez-Ibáñez, D. and Molyneux, P. (2011), "Efficiency and risk in european banking”, Journal of Banking and Finance, Vol. 35 No. 5, pp.1315-1326.

Flamini, V., Schumacher, M.L. and Mcdonald, M.C.A. (2009), The Determinants of Commercial Bank Profitability in Sub-Saharan Africa, International Monetary Fund.

Francis, W.B. and Osborne, M. (2012), "Capital requirements and bank behavior in the UK: are there lessons for international Capital standards?”, Journal of Banking and Finance, Vol. 36 No. 3, pp. 803-816.

Fu, X.M., Lin, Y.R. and Molyneux, P. (2014), "Bank competition and financial stability in asia pacific", Journal of Banking and Finance, Vol. 38, pp. 64-77.

Furlong, F.T. and Keeley, M.C. (1989), “Capital regulation and bank risk-taking: aA note”, Journal of Banking and Finance, Vol. 13 No. 6, pp. 883-891.

García-Herrero, A., Gavilá, S. and Santabárbara, D. (2009), "What explains the low profitability of chinese banks?”, Journal of Banking and Finance, Vol. 33 No. 11, pp. 2080-2092.

Geng, Z., Grivoyannis, E., Zhang, S. and He, Y. (2016), "The effects of the interest rates on bank risk in China: a panel data regression approach", International Journal of Engineering Business Management, Vol. 8, p. 1847979016662617.

Ghosh, S. (2014), "Risk, Capital and financial crisis: evidence for GCC banks", Borsa Istanbul Review, Vol. 14 No. 3, pp. 145-157.

Gischer, H. and Jüttner, D.J. (2001), Profitability and Competition in Banking Markets: an Aggregative Cross Country Approach, Univ., FEMM.

Goddard, J., Molyneux, P. and Wilson, J.O. (2004), "The profitability of european banks: a crosssectional and dynamic panel analysis", The Manchester School, Vol. 72 No. 3, pp. 363-381.

Goddard, J., Liu, H., Molyneux, P. and Wilson, J.O. (2013), "Do bank profits converge?”, European Financial Management, Vol. 19 No. 2, pp. 345-365.

Guidara, A., Soumaré, I. and Tchana, F.T. (2013), "Banks' Capital buffer, risk and performance in the canadian banking system: Impact of business cycles and regulatory changes", Journal of Banking and Finance, Vol. 37 No. 9, pp. 3373-3387.

Gujarati, D.N. (2009), Basic Econometrics, Tata McGraw-Hill Education.

Hao, J. and Zheng, K.K. (2016), "Bank equity Capital and risk-taking behavior: the effect of competition".

Ho, S.J. and Hsu, S.-C. (2010), “Leverage, performance and Capital adequacy ratio in taiwan's banking industry", Japan and the World Economy, Vol. 22 No. 4, pp. 264-272.

Hughes, J.P. and Mester, L.J. (1998), "Bank capitalization and cost: evidence of scale economies in risk management and signaling”, Review of Economics and Statistics, Vol. 80 No. 2, pp. 314-325.

Hussain, M.E. and Hassan, M.K. (2005), "Basel Capital requirements and bank credit risk taking in developing countries".

Iannotta, G. (2006), "Testing for opaqueness in the european banking industry: evidence from bond credit ratings", Journal of Financial Services Research, Vol. 30 No. 3, pp. 287-309.

Iannotta, G., Nocera, G. and Sironi, A. (2007), "Ownership structure, risk and performance in the european banking industry”, Journal of Banking and Finance, Vol. 31 No. 7, pp. 2127-2149.

Jacques, K. and Nigro, P. (1997), "Risk-based Capital, portfolio risk, and bank Capital: a simultaneous equations approach", Journal of Economics and Business, Vol. 49 No. 6, pp. 533-547.

Jiang, G., Tang, N., Law, E. and Sze, A. (2003a), Determinants of Bank Profitability in Hong Kong, Hong Kong Monetary Authority Research Memorandum, September.

Jiang, G., Tang, N., Law, E. and Sze, A. (2003b), The Profitability of the Banking Sector in Hong Kong, Hong Kong Monetary Authority Quarterly Bulletin.

Kahane, Y. (1977), "Capital adequacy and the regulation of financial intermediaries”, Journal of Banking and Finance, Vol. 1 No. 2, pp. 207-218. 
Karels, G.V., Prakash, A.J. and Roussakis, E. (1989), "The relationship between bank Capital adequacy and market measures of risk", Journal of Business Finance and Accounting, Vol. 16 No. 5, pp. 663-680.

Keeley, M.C. and Furlong, F.T. (1990), “A reexamination of mean-variance analysis of bank Capital regulation", Journal of Banking and Finance, Vol. 14 No. 1, pp. 69-84.

Kennedy, P. (2003), A Guide to Econometrics, MIT press.

Khan, A., Muttakin, M.B. and Siddiqui, J. (2013), "Corporate governance and corporate social responsibility disclosures: evidence from an emerging economy", Journal of Business Ethics, Vol. 114 No. 2, pp. 207-223.

Kim, D. and Santomero, A.M. (1988), "Risk in banking and Capital regulation", The Journal of Finance, Vol. 43 No. 5, pp. 1219-1233.

Koehn, M. and Santomero, A.M. (1980), "Regulation of bank Capital and portfolio risk", The Journal of Finance, Vol. 35 No. 5, pp. 1235-1244.

Kosmidou, K. (2008), “The determinants of banks' profits in Greece during the period of EU financial integration", Managerial Finance, Vol. 34 No. 3, pp. 146-159.

Laeven, L. and Levine, R. (2009), "Bank governance, regulation and risk taking”, Journal of Financial Economics, Vol. 93 No. 2, pp. 259-275.

Lee, T.H. and Chih, S.H. (2013), "Does financial regulation affect the profit efficiency and risk of banks? Evidence from china's commercial banks", The North American Journal of Economics and Finance, Vol. 26, pp. 705-724.

Lee, C.C. and Hsieh, M.F. (2013), "The impact of bank Capital on profitability and risk in asian banking", Journal of International Money and Finance, Vol. 32, pp. 251-281.

Lee, C.C., Ning, S.L. and Lee, C.C. (2015), "How does bank Capital affect bank profitability and risk? Evidence from china's WTO accession”, China and World Economy, Vol. 23 No. 4, pp. 19-39.

Lin, C. (1994), "The impact of government Capital adequacy on bank portfolio", Taipei Bank Monthly J, Vol. 25 No. 6, pp. 38-46.

Lin, S.L. Hwang, D.Y. Wang, K.L. and Xie, Z.W. (2013), "Banking Capital and risk-taking adjustment under Capital regulation: the role of financial freedom, concentration and governance control", International Journal of Management, Economics and Social Sciences, Vol. 2 No. 2, pp. 99-128.

Lin, S.L., Penm, J.H., Gong, S.C. and Chang, C.S. (2005), "Risk-based Capital adequacy in assessing on insolvency-risk and financial performances in taiwan's banking industry", Research in International Business and Finance, Vol. 19 No. 1, pp. 111-153.

Liu, M.Y., Kuo, C.J. and Wu, S. (1996), “The impact of risk-based Capital regulation on a bank's portfolio and insolvency risk", Research in Finance, Vol. 14, pp. 99-116.

Liu, H., Molyneux, P. and Wilson, J.O. (2013), "Competition and stability in european banking: a regional analysis", The Manchester School, Vol. 81 No. 2, pp. 176-201.

Liu, H. and Wilson, J.O. (2010), "The profitability of banks in Japan”, Applied Financial Economics, Vol. 20 No. 24, pp. 1851-1866.

Liu, H. and Wilson, J.O. (2013), "Competition and risk in japanese banking”, The European Journal of Finance, Vol. 19 No. 1, pp. 1-18.

Louzis, D.P., Vouldis, A.T. and Metaxas, V.L. (2012), "Macroeconomic and bank-specific determinants of non-performing loans in Greece: a comparative study of mortgage, business and consumer loan portfolios", Journal of Banking and Finance, Vol. 36 No. 4, pp. 1012-1027.

Majumder, M.T.H. and Uddin, M.J. (2017), "The determinants of profitability of nationalised banks in Bangladesh", International Journal of Economics and Business Research, Vol. 13 No. 4, pp. 335-348.

Majumder, M.T.H., Uddin, M.J. and Akter, A. (2018), "Does bank diversification significantly affect profitability? A longitudinal study on Bangladesh", Journal of Emerging Technologies and Innovative Research, Vol. 5 No. 9, pp. 162-169. 
JEFAS 23,46

Männasoo, K. and Mayes, D.G. (2009), "Explaining bank distress in Eastern european transition economies", Journal of Banking and Finance, Vol. 33 No. 2, pp. 244-253.

Mbizi, R. (2012), "An analysis of the impact of minimum Capital requirements on commercial bank performance in Zimbabwe", International Journal of Independent Research and Studies, Vol. 1 No. 4, pp. 124-134.

Molyneux, P. and Thornton, J. (1992), "Determinants of european bank profitability: a note", Journal of Banking and Finance, Vol. 16 No. 6, pp. 1173-1178.

Moon, C.G. and Hughes, J.P. (1997), "Measuring bank efficiency when managers trade return for reduced risk", Rutgers University, Department of Economics.

Naceur, S.B. (2003), The Determinants of the Tunisian Banking Industry Profitability: panel Evidence, Universite Libre de Tunis working papers, pp. 1-17.

Naceur, S.B. and Omran, M. (2011), "The effects of bank regulations, competition, and financial reforms on banks' performance", Emerging Markets Review, Vol. 12 No. 1, pp. 1-20.

Nickell, S. (1981), "Biases in dynamic models with fixed effects", Econometrica, Vol. 49 No. 6, pp. 1417-1426.

Nier, E. and Baumann, U. (2006), "Market discipline, disclosure and moral hazard in banking”, Journal of Financial Intermediation, Vol. 15 No. 3, pp. 332-361.

Pasiouras, F. and Kosmidou, K. (2007), "Factors influencing the profitability of domestic and foreign commercial banks in the european union", Research in International Business and Finance, Vol. 21 No. 2, pp. 222-237.

Poghosyan, T. and Čihak, M. (2011), "Determinants of bank distress in Europe: evidence from a new data set”, Journal of Financial Services Research, Vol. 40 No. 3, pp. 163-184.

Psillaki, M. and Mamatzakis, E. (2017), "What drives bank performance in transitions economies? The impact of reforms and regulations", Research in International Business and Finance, Vol. 39, pp. 578-594.

Rahman, M.M., Hamid, M.K. and Khan, M.A.M. (2015), "Determinants of bank profitability: empirical evidence from Bangladesh", International Journal of Business and Management, Vol. 10 No. 8, pp. 135-150.

Rime, B. (2001), "Capital requirements and bank behaviour: empirical evidence for Switzerland", Journal of Banking and Finance, Vol. 25 No. 4, pp. 789-805.

Shim, J. (2010), "Capital-based regulation, portfolio risk and Capital determination: empirical evidence from the US property-liability insurers", Journal of Banking and Finance, Vol. 34 No. 10, pp. 2450-2461.

Shrieves, R.E. and Dahl, D. (1992), "The relationship between risk and Capital in commercial banks", Journal of Banking and Finance, Vol. 16 No. 2, pp. 439-457.

Soedarmono, W. and Tarazi, A. (2016), "Competition, financial intermediation, and riskiness of banks: evidence from the Asia-Pacific region”, Emerging Markets Finance and Trade, Vol. 52 No. 4, pp. 961-974.

Soedarmono, W., Rous, P. and Tarazi, A. (2010), "Bank Capital requirement, managerial self-interest and risk-taking: evidence from Indonesian banks", LAPE Working Paper.

Sufian, F. (2012), "Determinants of bank profitability in developing economies: empirical evidence from the South asian banking sectors", Contemporary South Asia, Vol. 20 No. 3, pp. 375-399.

Sufian, F. and Habibullah, M.S. (2009), "Determinants of bank profitability in a developing economy: empirical evidence from Bangladesh", Journal of Business Economics and Management, Vol. 10 No. 3, pp. 207-217.

Tan, Y. (2016), "The impacts of risk and competition on bank profitability in China", Journal of International Financial Markets, Institutions and Money, Vol. 40, pp. 85-110. 
Tan, Y. and Floros, C. (2012a), "Bank profitability and GDP growth in China: a note", Journal of Chinese Economic and Business Studies, Vol. 10 No. 3, pp. 267-273.

Tan, Y. and Floros, C. (2012b), "Bank profitability and inflation: the case of China", Journal of Economic Studies, Vol. 39 No. 6, pp. 675-696.

Tan, Y. and Floros, C. (2012c), "Stock market volatility and bank performance in China", Studies in Economics and Finance, Vol. 29 No. 3, pp. 211-228.

Tan, Y. and Floros, C. (2013), "Risk, Capital and efficiency in chinese banking", Journal of International Financial Markets, Institutions and Money, Vol. 26, pp. 378-393.

Vollmer, U. and Wiese, H. (2013), "Minimum Capital requirements, bank supervision and special resolution schemes. Consequences for bank risk-taking”, Journal of Financial Stability, Vol. 9 No. 4, pp. 487-497.

Zhang, J., Jiang, C., Qu, B. and Wang, P. (2013), "Market concentration, risk-taking, and bank performance: evidence from emerging economies", International Review of Financial Analysis, Vol. 30, pp. 149-157.

Zhang, Z.Y., Jun, W. and Liu, Q.F. (2008), "Impacts of Capital adequacy regulation on risk-taking behaviors of banking", Systems Engineering-Theory and Practice, Vol. 28 No. 8, pp. 183-189.

Zheng, C. and Ashraf, B.N. (2014), "National culture and dividend policy: international evidence from banking”, Journal of Behavioral and Experimental Finance, Vol. 3, pp. $22-40$.

Zheng, C., Rahman, M., Begum, M. and Ashraf, B. (2017), "Capital regulation, the cost of financial intermediation and bank profitability: evidence from Bangladesh", Journal of Risk and Financial Management, Vol. 10 No. 2, p. 9.

Zhou, C. (2013), "The impact of imposing Capital requirements on systemic risk", Journal of Financial Stability, Vol. 9 No. 3, pp. 320-329.

\section{About the authors}

Md. Tofael Hossain Majumder is working as an Associate Professor of Accounting at Comilla University, Bangladesh. He completed MBA degree from the Donlinks School of Economics and Management, University of Science and Technology Beijing, P.R. China. Mr. Tofael has published in such scholarly journals as International Journal of Accounting and Information Management, International Journal of Economics and Business Research, Asian Economic and Financial Review, International Journal of Business and Technopreneurship, International Review of Management and Marketing, European Journal of Business and Management, The Journal of Comilla University, Journal of Management and Science and Jahangirnagar University Journal of Marketing. He is currently on the editorial board of a number of reputable refereed journals. He also attended several conferences as well. His research area includes corporate governance, risk management, project management, accounting and finance and human resource management. Md. Tofael Hossain Majumder is the corresponding author and can be contacted at: tofael_cou@yahoo.com

Dr Xiaojing Li is an Associate Professor of Accounting at Donlinks School of Economics and Management at the University of Science and Technology Beijing, China. She completed her PhD in Management Science and Engineering from the same university. Her current research includes analysis and application based on listed companies' financial information, corporate behavior and how to measure the financial result, IPO, venture capital and private equity and research on the business model. She published several books on accounting, as well as articles in reputed journals. She also attended many conferences.

For instructions on how to order reprints of this article, please visit our website: www.emeraldgrouppublishing.com/licensing/reprints.htm Or contact us for further details: permissions@emeraldinsight.com 